UDC 577.27

\title{
KINETICS OF INTERACTION BETWEEN POLYREACTIVE IMMUNOGLOBULINS AND ANTIGEN. THE THEORY
}

\author{
S. A. BOBROVNIK, M. O. DEMCHENKO, S. V. KOMISARENKO \\ Palladin Institute of Biochemistry, National Academy of Sciences of Ukraine, Kyiv; \\ e-mail: s-bobrov@ukr.net
}

Received: 14 February 2019; Accepted: 17 May 2019

\begin{abstract}
Dynamics of association between polyreactive immunoglobulins (PRIGs) and immobilized antigens is considered on the base of our model of PRIGs-antigen interaction, which was suggested by us earlier. This process of PRIGs binding to an immobilized antigen was described with a system of differential equations. The solution of this system of differential equations gives mathematical expressions that relate the dynam$i c s$ of the reactant concentrations and time of the reaction. Using Microsoft Excel program the theoretical curves were calculated and plotted that described the dynamics of "active", "nonactive" PRIGs in solution as well as PRIGs that were bound to an immobilized antigen. Conclusions drawn by us earlier about very high dependence of reaction PRIGs with an antigen from temperature were confirmed.
\end{abstract}

Ke y wo rd s: polyreactive immunoglobulins, kinetics of interaction, rate constants.

I n spite of a plenty of the experimental works [1-7] is devoted to studying of nonspecific of polyreactive antibodies, till now many features of their interaction with antigens remains poorly studied. PRIGs where discovered by us several decades ago $[8,9]$ as immunoglobulin molecules that acquire their properties after antibody treatment with high concentration chaotropic salts like KSCN or incubation in solutions at low/high $\mathrm{pH}$. It was established that PRIGs can interact nonspecifically with various structurally nonrelated antigens. Later our data were confirmed by others [10]. However it was not clear whether PRIGs are a part of the family so called low specific natural antibodies [11-14] or they represent a separate group of immunoglobulins that have individual biological functions and binding properties different from specific antibodies.

We also established earlier $[15,16]$, that the mechanism of PRIGs binding to antigens essentially differs from process of linkage between specific antibodies and appropriate antigen. Because of this the dynamics of PRIGs binding to an antigen also must differ from the dynamics of specific antibodies binding to conventional antigen. The matter is that specific antibodies are primordially complementary to the structure of appropriate antigens and owing to this they are capable to interact with each other without additional fitting. In contrast to specific antibodies the majority of PRIGs molecules are able to bind an antigen using hydrophobic patches, which in norm are buried inside of the molecule. However owing to molecular dynamics of PRIGs peptide chains some hydrophobic patches can appear on the surfaces of PRIGs for a short time. Because of this, such "activated" PRIGs molecules become to be able to interact with antigens by means of hydrophobic interaction. If the binding with antigens did not occur then mobile peptide chain of PRIG coiled in such a way that hydrophobic sites again become hidden inside of the molecule and, consequently, this molecule become "inactive".

If so, then it is evident that stoichiometry of PRIG-antigen interaction must differ substantially from interaction of specific antibodies and antigens. In the present paper we consider a scheme of such interaction and a system of differential equations that describe the dynamics of the process. The solution of this system allows to obtain algebraic expressions that describe kinetics of transformation "inactive" PRIGs into "active" ones and PRIGs binding to an

(C) 2019 Bobrovnik S. A. et al. This is an open-access article distributed under the terms of the Creative Commons Attribution License, which permits unrestricted use, distribution, and reproduction in any medium, provided the original author and source are credited. 
immobilized antigen. Using these expressions the theoretical curves for all reactants were calculated for different values of rate constants.

\section{Results and Discussion}

If "inactive" PRIGs, $N$, can gradually and reversibly be transformed into "active" PRIGs with rate constant $k_{1}$ and inversely with rate constant $k_{2}$, and if only "active" PRIGs, A, can bind to immobilized antigen with rate constant $k_{3}$ and become bond PRIGs, C, then the scheme of this reaction will be following:

$$
N \underset{k_{2}}{\stackrel{k_{1}}{\rightleftarrows}} A \stackrel{k_{3}}{\longrightarrow} C
$$

Then dynamics of the process will be described by following system of the differential equations:

$$
\left\{\begin{array}{c}
\frac{d N}{d t}=k_{2} A-k_{1} N \\
\frac{d A}{d t}=k_{1} N-\left(k_{2}+k_{3}\right) A \\
\frac{d C}{d t}=k_{3} A
\end{array}\right.
$$

where $N$ - concentration of "inactive" PRIGs in the solution; $A$ - concentration of "active" PRIGs in the solution; $C$ - concentration of PRIGs bond to immobilized antigen; $k_{1}$ - rate constant of the transformation of "inactive" PRIGs into "active" PRIGs; $k_{2}$ - rate constant of the transformation of "active" PRIGs into "inactive" PRIGs; $k_{3}$ - rate constant of the binding of "active" PRIGs to immobilized antigen.

To solve this system of the differential equations, we have to integrate the first equation of the system (2) on t and we will obtain:

$$
\frac{d^{2} N}{d t^{2}}=k_{2} \frac{d A}{d t}-k_{1} \frac{d N}{d t}
$$

From the first equation of system (2) it is possible to receive also, that:

$$
A=\frac{1}{k_{2}} \times \frac{d N}{d t}+\frac{k_{1} N}{k_{2}}
$$

Having substituted in the equation (3) value of $\frac{d A}{d t}$, presented by the second equation from system of the differential equations (2), we shall get:

$$
\frac{d^{2} N}{d t^{2}}=k_{2}\left[k_{1} N-\left(k_{2}+k_{3}\right) A\right]-k_{1} \frac{d N}{d t}
$$

Now we can substitute in the equation (5) value $A$, presented by the equation (4). Then we will obtain:

$$
\begin{aligned}
& \frac{d^{2} N}{d t^{2}}=k_{1} k_{2} N-\left(k_{2}+k_{3}\right) \times \\
& \times\left(\frac{d N}{d t}+\frac{k_{1} N}{k_{2}}\right)-k_{1} \frac{d N}{d t}
\end{aligned}
$$

After performance of algebraic actions in the equation (6) we shall receive the following equation:

$$
N^{\prime \prime}+\left(k_{1}+k_{2}+k_{3}\right) N^{\prime}+k_{1} k_{3} N=0
$$

Let's make following designations: $k_{1}+k_{2}+$ $+k_{3}=b ; k_{1} k_{3}=c$. Then instead of the equation (7) we will get:

$$
N^{\prime \prime}+b N^{\prime}+c N=0
$$

Consequently, the characteristic equation for system of the differential equations (2) will be:

$$
r^{2}+b r+c=0
$$

Apparently, that decision of the equation (9) are following expressions:

$$
r_{1}=\frac{-b+\sqrt{b^{2}-4 c}}{2}, \quad r_{2}=\frac{-b-\sqrt{b^{2}-4 c}}{2}
$$

if $b^{2}-4 c \geq 0$.

From this it follows, that

$$
N=Z_{1} e^{r_{1} t}+Z_{2} e^{r_{2} t}
$$

Let's consider now the second equation of differential system (2):

$$
\frac{d A}{d t}=k_{1} N-\left(k_{2}+k_{3}\right) A
$$

Let's transform it to a type

$$
\frac{d A}{d t}+\left(k_{2}+k_{3}\right) A=k_{1} N
$$

Having equated to zero the right part of the equation (13), we shall receive:

$$
\frac{d A}{d t}+\left(k_{2}+k_{3}\right) A=0
$$

Consequently

$$
\frac{d A}{d t}=-\left(k_{2}+k_{3}\right) A
$$

Having integrated the equation (15), we will obtain:

$$
A=X e^{-\left(k_{2}+k_{3}\right) t}
$$

where $X$ - is some unknown function from t which should be determined. 
To find the unknown function $X$, let us differentiate equation (16) on $t$ and we will get:

$$
\begin{aligned}
& \frac{d A}{d t}=\frac{d X}{d t} e^{-\left(k_{2}+k_{3}\right) t}- \\
& -X\left(k_{2}+k_{3}\right) e^{-\left(k_{2}+k_{3}\right) t}
\end{aligned}
$$

Now we shall substitute value $A$ from the equation (16) and value $\frac{d A}{d t}$ from the equation (17) in the equation (13). From this we will receive:

$$
\frac{d X}{d t}=k_{1} N e^{\left(k_{2}+k_{3}\right) t}
$$

Now an expression for $N$, received from the equation (11), we can substitute into equation (18):

$$
\frac{d X}{d t}=k_{1}\left(Z_{1} e^{r_{1} t}+Z_{2} e^{r_{2} t}\right) e^{\left(k_{2}+k_{3}\right) t}
$$

Having integrated equation (19), we will receive:

$$
\begin{aligned}
& X=k_{1} \int\left(Z_{1} e^{r_{1}}+Z_{2} e^{r_{2}}\right) e^{\left(k_{2}+k_{3}\right) t}= \\
& =\frac{k_{1} Z_{1} e^{\left(r_{1}+k_{2}+k_{3}\right) t}}{r_{1}+k_{2}+k_{3}}+\frac{k_{1} Z_{2} e^{\left(r_{2}+k_{2}+k_{3}\right) t}}{r_{2}+k_{2}+k_{3}}
\end{aligned}
$$

Then, knowing $X$, from the equation (16) it is possible to receive value $A$ :

$$
A=X e^{-\left(k_{2}+k_{3}\right) t}=\frac{k_{1} Z_{1} e^{r_{1} t}}{r_{1}+k_{2}+k_{3}}+\frac{k_{1} Z_{2} e^{r_{2} t}}{r_{2}+k_{2}+k_{3}}
$$

Now, in order to find values $Z_{1}$ and $Z_{2}$, we have to consider following initial conditions of this reaction. Apparently, that in an initial moment of the reaction, i.e. at $t=0$, in a solution there is the initial mixture of active and inactive molecules of PRIGs is equal to $S$, whereas concentration of PRIGs bond to immobilized antigen is equal to zero, i.e. $C=0$. As far as between "active" and "inactive" PRIGs there is a dynamic equilibrium then it is easy to find, that at a starting point of time (at $t=0$ ) concentration of "active" PRIGs, $A$, is equal to

$$
A=\frac{k_{1} S}{k_{1}+k_{2}}
$$

and concentration of "inactive" PRIGs, $N$, is equal to

$$
N=\frac{k_{2} S}{k_{1}+k_{2}}
$$

From the equation (11) it follows, that at $t=0$, $N=Z_{1}+Z_{2}$ and then in view of equation (23) it is possible to receive the first equation for searching the unknown values $Z_{1}$ и $Z_{2}$ :

$$
\frac{k_{2} S}{k_{1}+k_{2}}=Z_{1}+Z_{2}
$$

From the equation (21) we also can find, that at $t=0, A=\frac{k_{1} Z_{1}}{r_{1}+k_{2}+k_{3}}+\frac{k_{1} Z_{2}}{r_{2}+k_{2}+k_{3}}$. In view of equation (22) it is possible to receive the second equation for searching two unknown values $Z_{1}$ and $Z_{2}$ :

$$
\frac{k_{1} S}{k_{1}+k_{2}}=\frac{k_{1} Z_{1}}{r_{1}+k_{2}+k_{3}}+\frac{k_{1} Z_{2}}{r_{2}+k_{2}+k_{3}}
$$

Thus, it is possible to receive system of two algebraic equations, (24) and (25), that have two unknowns, $Z_{1}$ and $Z_{2}$.

$$
\left\{\begin{array}{c}
\frac{k_{2} S}{k_{1}+k_{2}}=Z_{1}+Z_{2} \\
\frac{k_{1} S}{k_{1}+k_{2}}=\frac{k_{1} Z_{1}}{r_{1}+k_{2}+k_{3}}+\frac{k_{1} Z_{2}}{r_{2}+k_{2}+k_{3}}
\end{array}\right.
$$

The solution of this system of equations allows to find following values of unknown $Z_{1}$ and $Z_{2}$ :

$$
\begin{aligned}
& Z_{1}=\frac{S\left(r_{2}+k_{3}\right)\left(r_{1}+k_{2}+k_{3}\right)}{\left(k_{1}+k_{2}\right)\left(r_{2}-r_{1}\right)} \\
& Z_{2}=\frac{k_{2} S\left(r_{2}-r_{1}\right)-S\left(r_{2}+k_{3}\right)\left(r_{1}+k_{2}+k_{3}\right)}{\left(k_{1}+k_{2}\right)\left(r_{2}-r_{1}\right)}
\end{aligned}
$$

Now, knowing sizes $Z_{1}$ and $Z_{2}$, it is possible to substitute their values in the equations (11) and (21) to receive algebraic expressions for $N$ and $A$, describing dynamics of these components:

$$
\begin{aligned}
& N=\frac{S\left(r_{2}+k_{3}\right)\left(r_{1}+k_{2}+k_{3}\right)}{\left(k_{1}+k_{2}\right)\left(r_{2}-r_{1}\right)} e^{r_{1} t}+ \\
& +\frac{S\left[k_{2}\left(r_{2}-r_{1}\right)-\left(r_{2}+k_{3}\right)\left(r_{1}+k_{2}+k_{3}\right)\right]}{\left(k_{1}+k_{2}\right)\left(r_{2}-r_{1}\right)} e^{r_{2} t} \\
& A=\frac{k_{1} S\left(r_{2}+k_{3}\right)}{\left(k_{1}+k_{2}\right)\left(r_{2}-r_{1}\right)} e^{r_{1} t}+ \\
& +\frac{k_{1} S\left[k_{2}\left(r_{2}-r_{1}\right)-\left(r_{2}+k_{3}\right)\left(r_{1}+k_{2}+k_{3}\right)\right]}{\left(k_{1}+k_{2}\right)\left(r_{2}-r_{1}\right)\left(r_{2}+k_{2}+k_{3}\right)} e^{r_{2} t}
\end{aligned}
$$

And, finally, to find the equation describing dynamics of value $C$, we will use following information. It is obvious that the total quantity of PRIGs which can be designated as $S$, is equal to the sum of “active” PRIGs, A, “inactive" PRIGs, N, and boned to antigen PRIGs, $C$, i.e.:

$$
S=A+N+C
$$

From this it follows, that subtracting from the total PRIGs concentration equal to $S$, the values of $A$ and $N$, presented by the equations (29) and (30), we shall receive the equation describing the dynamics of PRIGs amount boned to immobilized antigen, i.e. value of $C$ : 


$$
\begin{aligned}
& C=S-\frac{S\left(r_{2}+k_{3}\right)\left(r_{1}+k_{2}+k_{3}\right)}{\left(k_{1}+k_{2}\right)\left(r_{2}-r_{1}\right)} e^{r_{1} t}- \\
& -\frac{S\left[k_{2}\left(r_{2}-r_{1}\right)-\left(r_{2}+k_{3}\right)\left(r_{1}+k_{2}+k_{3}\right)\right]}{\left(k_{1}+k_{2}\right)\left(r_{2}-r_{1}\right)} e^{r_{2} t}- \\
& -\frac{k_{1} S\left(r_{2}+k_{3}\right)}{\left(k_{1}+k_{2}\right)\left(r_{2}-r_{1}\right)} e^{r_{1} t}- \\
& -\frac{k_{1} S\left[k_{2}\left(r_{2}-r_{1}\right)-\left(r_{2}+k_{3}\right)\left(r_{1}+k_{2}+k_{3}\right)\right]}{\left(k_{1}+k_{2}\right)\left(r_{2}-r_{1}\right)\left(r_{2}+k_{2}+k_{3}\right)} e^{r_{2} t}
\end{aligned}
$$

where $r_{1}=\frac{-\left(k_{1}+k_{2}+k_{3}\right)+\sqrt{\left(k_{1}+k_{2}+k_{3}\right)^{2}-4 k_{1} k_{3}}}{2}$

and $r_{2}=\frac{-\left(k_{1}+k_{2}+k_{3}\right)-\sqrt{\left(k_{1}+k_{2}+k_{3}\right)^{2}-4 k_{1} k_{3}}}{2}$.

Thus, we received three equations, (29), (30) and (32), that describe the dynamics of all three components, $N, A$ и $C$, for the considering reaction between PRIGs and immobilized antigen. Owing to this there is an ability to calculate the theoretical curves describing changes of each components and to find out, how variations of rate constants influences on a type of these curves.

Even before calculation of theoretical curves it was obviously, that in case of equality of rate constants $k_{1}$ and $k_{2}$, quantities PRIGs, a being in "active" and "inactive" states, i.e. $N$ and $A$, will be equal to each other in an initial moment of reaction and during reaction their amount gradually decrease to zero. The amount of bond PRIGs, $C$, which at initial moment of the reaction is equal to zero, should increase constantly till all available PRIGs bind to immobilized antigen. Really, such type of curves was received (Fig. 1) when theoretical curves were calculated for follow parameters: $S=1 \mu \mathrm{M}$, $k_{1}=0.001 \mathrm{sec}^{-1} ; k_{2}=0.001 \mathrm{sec}^{-1} ; k_{3}=0.004 \mathrm{sec}^{-1}$. From these curves also it is also apparently, that during 70 mines of the reaction at the given values of constants of speed almost all PRIGs will bind to antigen, and values $N$ and $A$ will come close to zero.

If the value of $k_{2}$ will increase fourfold but all other parameters of reaction will remain stay the same then the relation concentration of "inactive" and "active" PRIGs also will increase 4 times ( $N=80 \%$ и $A=20 \%$ ), and the reaction will proceed much more slowly (Fig. 2). In this case during 70 mines about $85 \%$ of existing in solution PRIGs will bond to immobilized antigen.

If the value of $k_{2}$ will increase fourfold and the other parameters of reaction will be the same as in Fig. 1, then kinetics curves of PRIGs dynamics will get a type presented on Fig. 3. As it can be seen from Fig. 3 , in this case in the initial sample the quantity of "active" PRIGs will exceed fourfold the quantity of "inactive" PRIGs and reaction will proceed noticeably more quickly, than in two above cases. At the given rate constants the reaction practically will come to the end through $30 \mathrm{~min}$.

However, the basic interest for us represents the curves of the dynamics PRIGs of binding to immobilized antigen, i.e. curves for $C$. The matter is that just these curves can be obtained in experiment, whereas dynamics of $N$ and $A$ hardly cold be measured in experiment. For this reason let us consider several kinetic curves (Fig. 4) where the theoretical kinetic curves describe the dynamics of $C$ at various

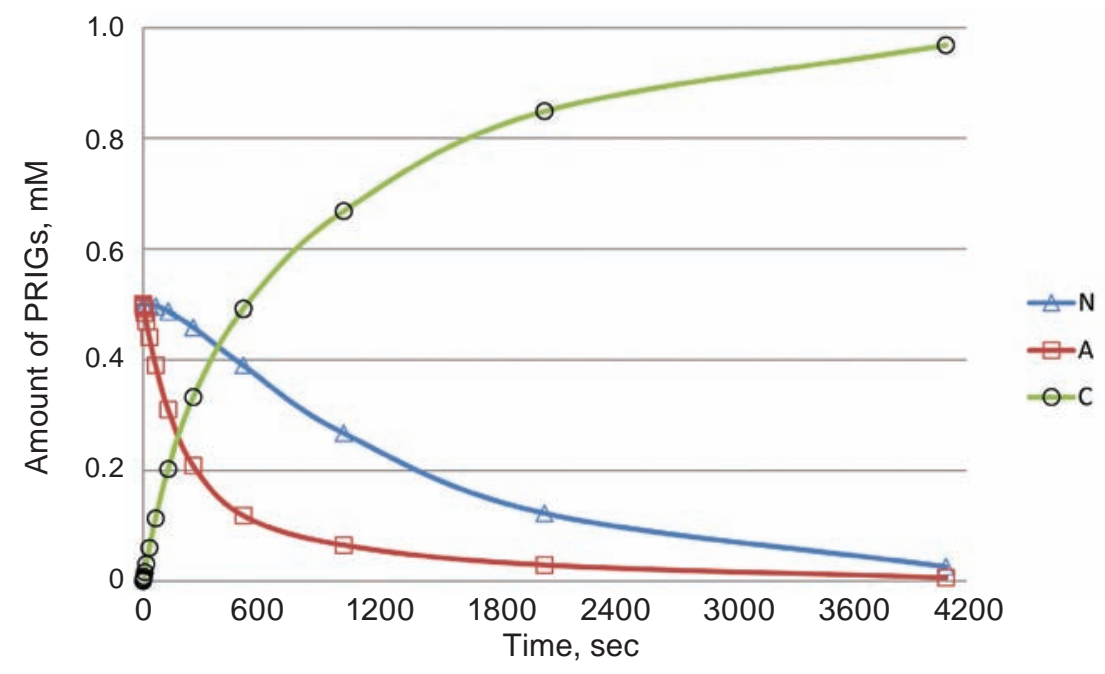

Fig. 1. Theoretical curves for values $N, A$, and $C$ were calculated for follow parameters: $S=1 \mu M$, $k_{1}=0.001 \mathrm{sec}^{-1} ; k_{2}=0.001 \mathrm{sec}^{-1} ; k_{3}=0.004 \mathrm{sec}^{-1}$ 


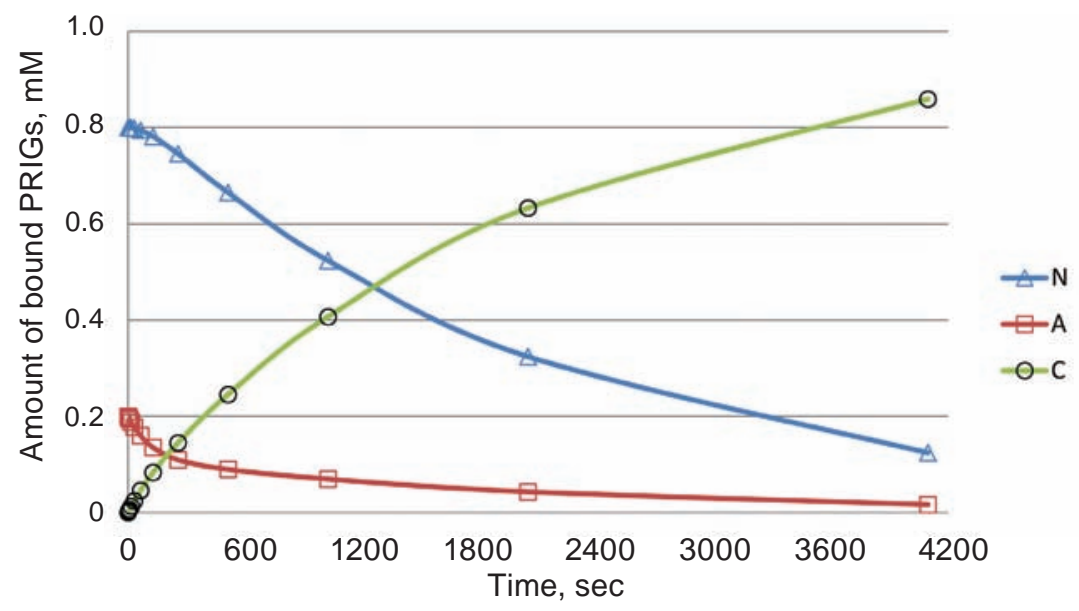

Fig. 2. Theoretical curves for values $N, A$, and $C$ were calculated for follow parameters: $S=1 \mu M$, $k_{1}=0.001 \mathrm{sec}^{-1} ; k_{2}=0.004 \mathrm{sec}^{-1} ; k_{3}=0.004 \mathrm{sec}^{-1}$

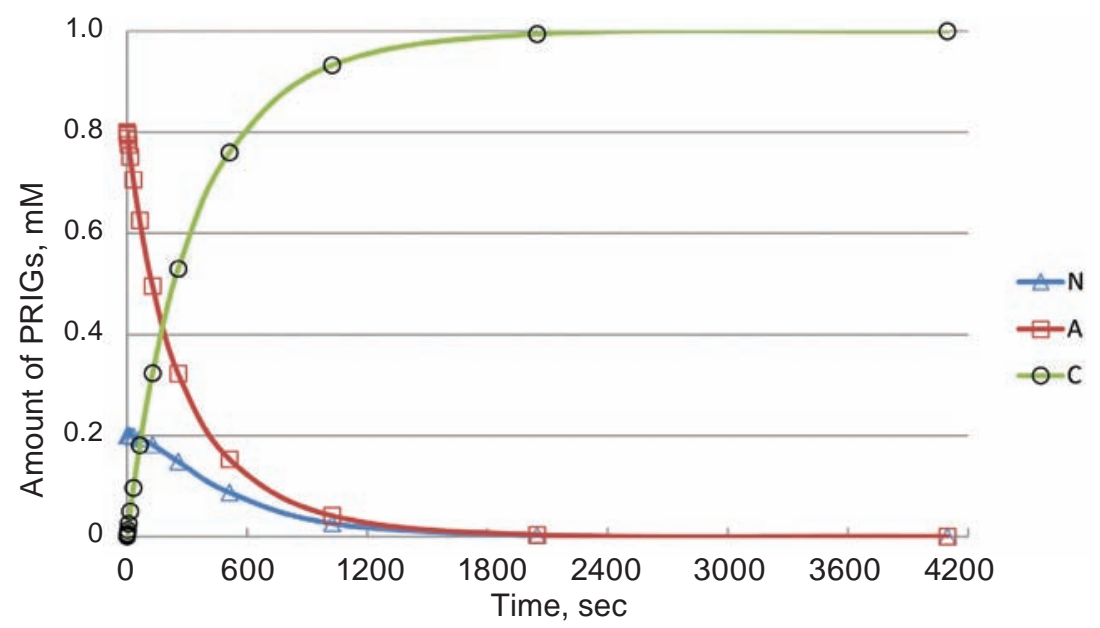

Fig. 3. Theoretical curves for values $N, A$, and $C$ were calculated for follow parameters: $S=1 \mu M$, $k_{1}=0.004 \sec ^{-1} ; k_{2}=0.001 \sec ^{-1} ; k_{3}=0.004 \sec ^{-1}$

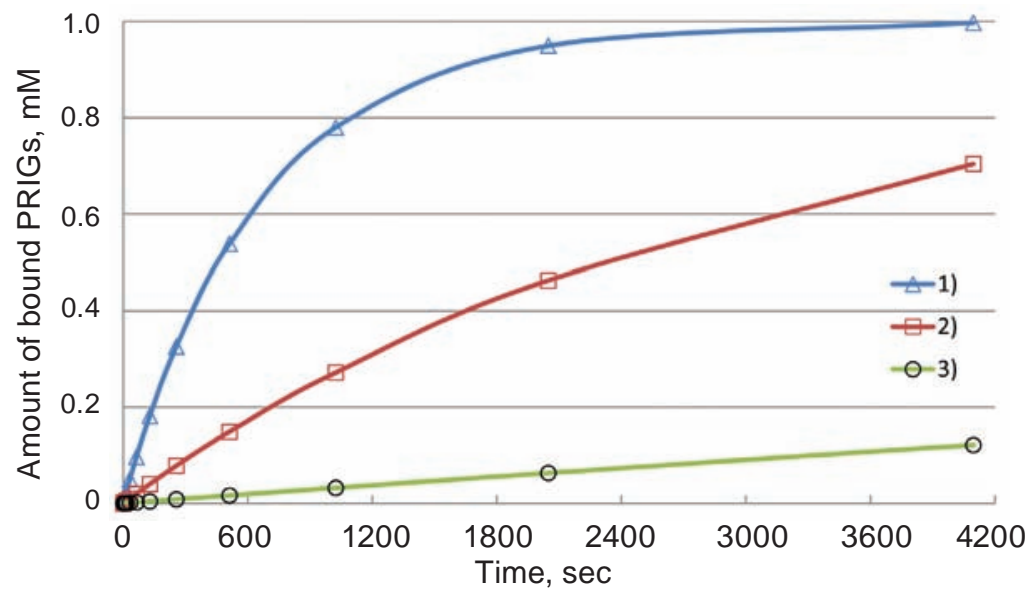

Fig.4. Theoretical curves for $C$ values were calculated for follow parameters: $S=1 \mu M$; 1) $k_{1}=0.004 \sec ^{-1}$; $k_{2}=0.001 \mathrm{sec}^{-1} ; k_{3}=0.002 \mathrm{sec}^{-1}$. 2) $k_{1}=0.0008 \mathrm{sec}^{-1} ; k_{2}=0.0002 \mathrm{sec}^{-1} ; k_{3}=0.0004 \mathrm{sec}^{-1} ;$ 3) $k_{1}=0.00008 \mathrm{sec}^{-1}$; $k_{2}=0.00002 \mathrm{sec}^{-1} ; k_{3}=0.00004 \mathrm{sec}^{-1}$ 


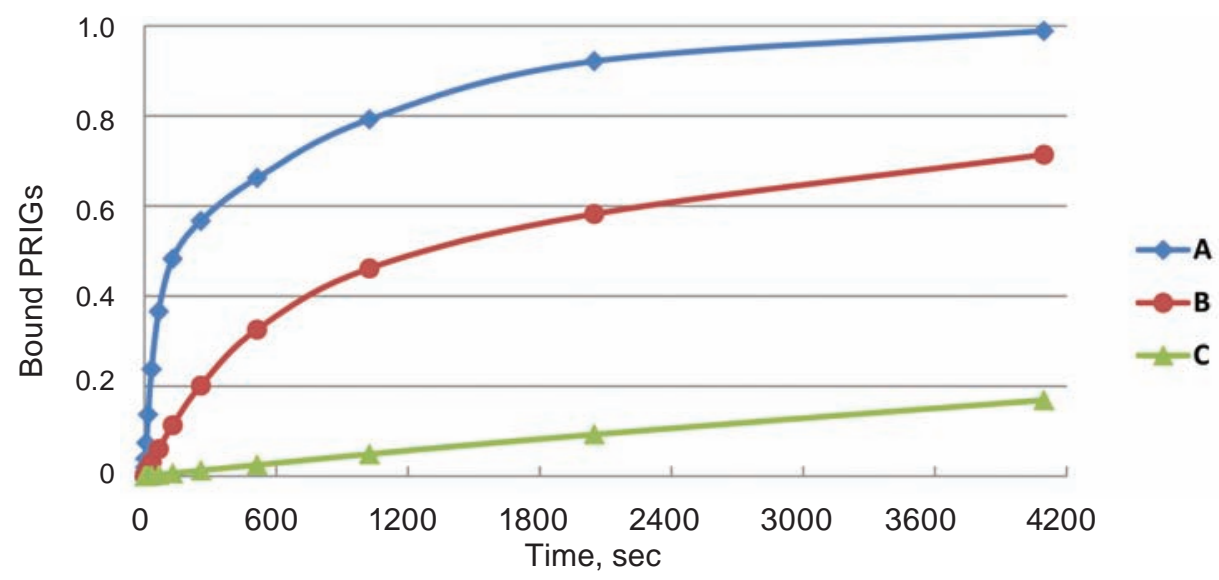

Fig. 5. Experimental curves for PRIGs binding to immobilized antigen at temperatures $37^{\circ} \mathrm{C}(\mathrm{A}), 17^{\circ} \mathrm{C}(\mathrm{B})$ and $2{ }^{\circ} \mathrm{C}(\mathrm{C})[17]$

values of rate constants and which are similar to that usually were obtained in our former experiments [17]. These three curves were calculated for the following parameters: $S=1 \mu \mathrm{M}$, and 1) $k_{1}=0.001 \mathrm{sec}^{-1}$; $k_{2}=0.001 \mathrm{sec}^{-1} ; k_{3}=0.004$ sec-1. 2) $k_{1}=0.001 \mathrm{sec}^{-1}$; $k_{2}=0.001 \mathrm{sec}^{-1} ; k_{3}=0.004 \mathrm{sec}-1$. 3) $k_{1}=0.001 \mathrm{sec}^{-1}$; $k_{2}=0.001 \mathrm{sec}^{-1} ; k_{3}=0.004 \mathrm{sec}^{-1}$.

As it can be seen from Fig. 4, at these rate constants more than $95 \%$ of all PRIGs should be bound to immobilized antigen during 3600 sec, i.e. for $1 \mathrm{~h}$. Reduction of all rate constants in 5 times (see curve 2) leads to decrease in speed of PRIGs binding to the antigen, though more than 60\% PRIGs still be bound for $1 \mathrm{~h}$. If all the rate constants will lower in 50 times then only $10 \%$ of PRIGs will bound to antigen for $1 \mathrm{~h}$.

It is important to note, that experimental curve of PRIGs to immobilized antigen at temperatures $2{ }^{\circ} \mathrm{C}, 17^{\circ} \mathrm{C}$ and $37^{\circ} \mathrm{C}$ that were obtained by us earlier [18] very remind the theoretical curves presented on Fig. 4. This obviously means that decrease of the temperature from $37{ }^{\circ} \mathrm{C}$ up to $2-4^{\circ} \mathrm{C}$ is accompanied, apparently, by decrease in values of rate constants also about in 50 times. This extremely high degree of the dependence of rate constants from temperature tells us about very high energy of activation for considered reaction, i.e. for PRIGs binding to antigen. Thus, the data obtained in the present article confirm conclusions drawn by us earlier [17] that PRIGs binding to antigen depends on temperature much more strongly, than interaction of specific antibodies with corresponding antigen. This dependence, probably, is caused by necessity of structural changes of PRIGs for their binding with antigens.
Conflict of interest. Authors have completed the Unified Conflicts of Interest form at http:// ukrbiochemjournal.org/wp-content/uploads/2018/12/ coi_disclosure.pdf and declare no conflict of interest.

\section{КІНЕТИКА ВЗАЕМОДІЇ ПРІГ З ІММОБІЛІЗОВАНИМИ АНТИГЕНАМИ. ТЕОРІЯ}

\section{С. П. Бобровник, М. О. Демченко, \\ С. В. Комісаренко}

Інститут біохімії ім. О. В. Палладіна НАН України, Київ; e-mail: s-bobrov@bk.ru

Розглянуто динаміку зв'язування поліреактивних імуноглобулінів (ПРІГ) 3 іммобілізованим на імунологічних платах антигеном із врахуванням раніше встановленого нами механізму взаємодії ПРІГ з антигенами. Процес зв'язування ПРІГ з іммобілізованим антигеном описано за допомогою систем диференціальних рівнянь, розв'язання яких дозволило одержати математичні вирази залежності кількості «активних» i «неактивних» ПРІГ, а також ПРІГ, зв'язаних із іммобілізованим антигеном залежно від часу перебігу реакції. За допомогою програми Microsoft Excel проведено обчислення теоретичних кривих кінетики зв'язування ПРІГ із антигеном і кількості «активних» та «неактивних» ПРІГ у розчині за різних констант швидкості реакції. Підтверджено раніше зроблені нами висновки про дуже високу залежність реакції ПРІГ 3 антигенами від температури. 
К л ю чо в і с ло в а: поліреактивні імуноглобуліни, кінетика взаємодії, константи швидкості.

\section{References}

1. Liao H, Zhang Z. Polyreactive Antibodies in Anti-HIV-1 Responses. Curr Mol Med. 2018; 18(2): 126-133.

2. Zorn E, See SB. Polyreactive natural antibodies in transplantation. Curr Opin Organ Transplant. 2017; 22(1): 8-13.

3. Lecerf M, Jarossay A, Kaveri SV, LacroixDesmazes S, Dimitrov JD. Methods for Posttranslational Induction of Polyreactivity of Antibodies. Methods Mol Biol. 2017; 1643: 135145.

4. Gunti S, Notkins AL. Polyreactive Antibodies: Function and Quantification. J Infect Dis. 2015; 212(Suppl 1): S42-S46.

5. Dimitrov JD, Planchais C, Roumenina LT, Vassilev TL, Kaveri SV, Lacroix-Desmazes S. Antibody polyreactivity in health and disease: statu variabilis. J Immunol. 2013; 191(3): 993999.

6. Mahendra A, Gangadharan B, André S, Boudjoghra M, Davi F, Lecerf M, Planchais C, Kaveri SV, Lacroix-Desmazes S, Dimitrov JD. Cryptic polyreactivity of IgG expressed by splenic marginal zone B-cell lymphoma. Mol Immunol. 2014; 60(1): 54-61.

7. Zhou ZH, Tzioufas AG, Notkins AL. Properties and function of polyreactive antibodies and polyreactive antigen-binding $\mathrm{B}$ cells. J Autoimmun. 2007; 29(4): 219-228.

8. Bobrovnik SA, Liashchenko KP, Komisarenko SV. Polyspecific antibodies and their activation. Proc Nat Acad Ukraine. 1990; (6): 71-74. (In Russian).
9. Bobrovnik SA. Activation of "silent" antibodies and their interaction with antigens. Ukr Biokhim Zhurn. 1990; 62(5): 86-89. (In Russian).

10. Bouvet JP, Stahl D, Rose S, Quan CP, Kazatchkine MD, Kaveri SV. Induction of natural autoantibody activity following treatment of human immunoglobulin with dissociating agents. J Autoimmun. 2001; 16(2): 163-172.

11. Avrameas S. Natural autoantibodies: from 'horror autotoxicus' to 'gnothi seauton'. Immunol Today. 1991; 12(5): 154-159.

12. Avrameas S, Ternynck T. The natural autoantibodies system: between hypotheses and facts. Mol Immunol. 1993; 30(12): 1133-1142.

13. Notkins AL. Polyreactivity of antibody molecules. Trends Immunol. 2004; 25(4): 174179.

14. Zhou ZH, Zhang Y, Hu YF, Wahl LM, Cisar JO, Notkins AL. The broad antibacterial activity of the natural antibody repertoire is due to polyreactive antibodies. Cell Host Microbe. 2007; 1(1): 51-61.

15. Bobrovnik SA. Polyreactive immunoglobulins recognize hydrophobic parts of proteins. $U k r$ Biokhim Zhurn. 2001; 73(2): 116-122. (In Russian).

16. Bobrovnik SA. Mechanisms of interaction of polyreactive immunoglobulins and protein antigens. Ukr Biokhim Zhurn. 2002;74(2): 37-44. (In Russian).

17. Bobrovnik SA. Dynamics of the interaction of polyreactive immunoglobulins with immobilized antigens. Ukr Biokhim Zhurn. 1998; 70(6): 135143. (In Russian). 